\title{
利用者の分布を考慮した施設配置分析
}

\author{
降篗徹馬、松岡公二
}

\section{A Facility Location Analysis Considering Spatial Patterns of Distributed Users}

\author{
Tetsuma FURIHATA and Koji MATSUOKA
}

\begin{abstract}
Facility location and area-marketing analysis by Geographical Information System(GIS) frequently require distance from facility to user and aggregated user population in areas of concern. This is usually based on estimating the user distribution from the aggregated population data for each area consisting of unit areas which is assumed that the user distributes evenly. However, for the spread of much more detailed geographical data available for certain urban areas, we do not estimate only the user distribution incorporating aggregated data approximately but also estimate it as points data of individual buildings in the area. In this paper we confirm the effectiveness of this latest approach by comparing its result to that produced by the convertional method of data aggregation.
\end{abstract}

Keywords: GIS, locational analysis, area-marketing, spatial pattern.

\section{1.はじめに}

近年の地理情報システム(GIS)に対する関心は高 く、多くの分野において様々な利用を目的とした研 究・開発が進められている。同時に、その中心をな す地図デー夕も各方面において徐々に整備されつつ ある。その中で個々の施設の存在や位置づけをより 詳細に把握することが可能なものとして、建物、道 路をはじめとした情報が格納された住宅地図データ があり、地方自治体や民間の業者によって作成・蓄 積されている。現在、これらのデータをいかに活用 していくかが重要なテーマとなっている。 この住宅地図データは、施設配置分析やエリアマー ケティング分析に揖ける施設とその利用者の空間的 関連を基にした分析手法に有効に利用できる可能性 を持っている。すなわち、施設が利用者に対して提 供するサービスの状熊を距離に関して明らかにする 距離分布(大澤・腰塚,1983)や、施設が抱えると推測

降旛：T346 埼玉県久喜市下清久500 東京理科大学経営学部 500 Simo-kiyohisa, Kuki-shi, Saitama 346
される利用者の数、すなわち利用圈(商業施設なら ば商圈)に関する諸性質について、より現実に近い 観点から分析が可能な点である。

これら諸性質の分析のためには，利用者から施設 までの距離の算出や利用圈内の利用者数の集計(人 口推計)といった基本的な処理が必ず伴う。ここで の利用者分布(人口分布)の捉え方が分析の精度を向 上させる上で重要な項目であり、いかに現実の問題 に即応して分析が行えるかどうかがこのような地図 デー夕を利用したGISの構築を成功させるキーポイ ントとなるものと考えられる。

既往のほとんどの研究では、利用者を把握するた めのデータとして番地や丁目の街区単位やメッシュ 単位に集約された集計データが利用されてきた。こ の集計データでは集計単位以下の区分に扔いて生ず る利用者分布の相違が把握できない。

ある利用圈が与えられ、この利用圈に含まれる利 用者数をこの利用圈と重ならない(完全一致しない) 集計データから求める場合は、各々の面上で幾何学 的にズレを生じた部分を補正し求める方法が提案さ 


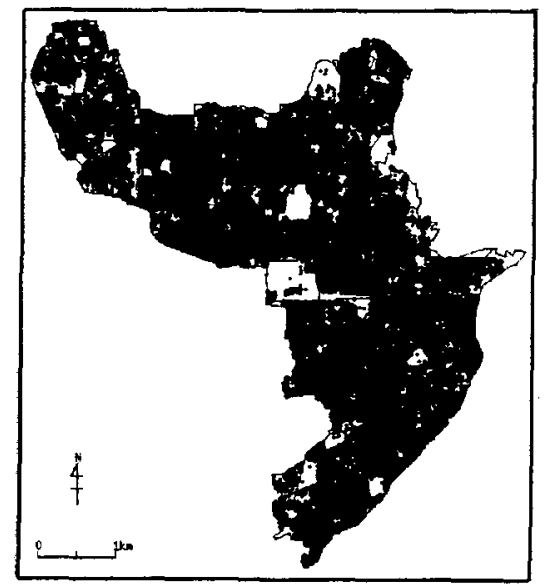

(a)建物

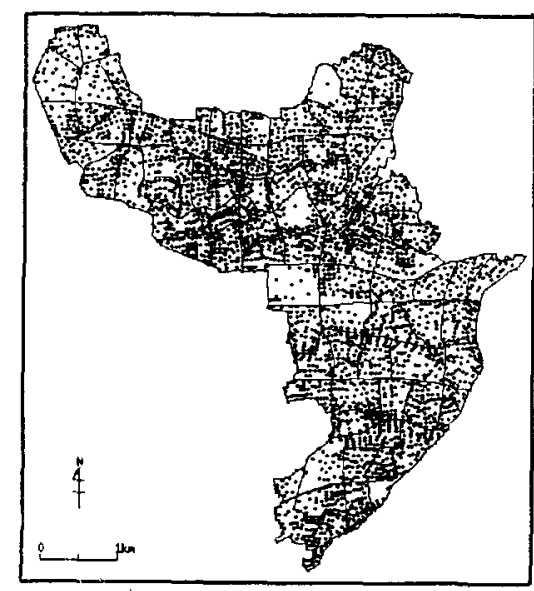

(b)番地

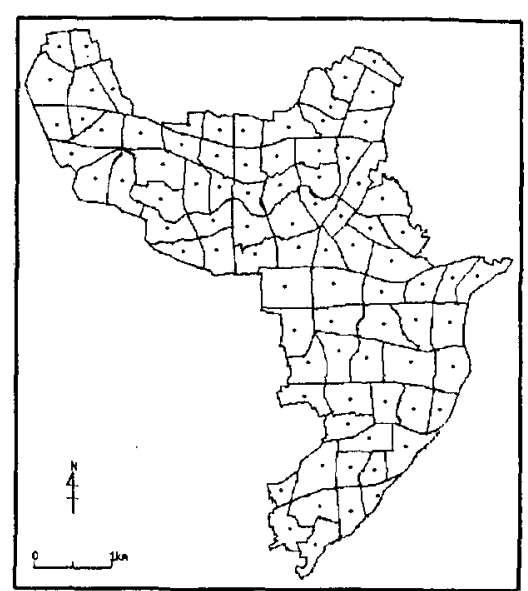

(c)丁目

図1＼cjkstart東京都中野区における人口分布

れている(鶴谷ら,1985)。しかし、この方法において も、個々の集計単位内での人口分布を一様分布と仮 定して取り扱っているため、集計単位以下の区分に おいて生ずる人口分布の相違を考虑することは不可 能である。

現在の都市における人口分布パターンは、高層の集 合住宅や公園等の影響で著しく変化の激しい状況を 呈すると考えなければならず、街区やメッシュ単位 に集約して取り扱う人ロデータでは样々な分析手段 に対して十分な精度の結果を与えるものではないと 考えられる。

そこで、施設とその利用者の空間的関連を基にし た分析手法に、住宅地図レベルの地図データから得 られる建物分布に関するデー夕を利用者分布を捉え るデータとして利用することを提唱する。

建物は人間が生活を営む上での基本的な単位であ り、利用者分布を建物分布とオーバラップして捉え ることは、現実の人口分布を最も細かい単位の位置 情報を付随させて取り扱えることであり、様々な利 点が生ずる可能性がある。特にこの方法によれば、 利用者から施設までの距離や，利用圈内の利用者数 を人口分布バターンのいかような変化をも克服し、 より精度よく算出できる点をあげることができる。 また、利用者分布を点として取り扱えるため、地域 住民に対する利便度を考虑した施設の最適配置の導 出、すなわち連続立地型のminisum問題やminimax問
題などに適用し、より現実に近い状況下で施設配置 の評価に活用できる。

しかし、利用者分布を建物ごとに捉えて分析を行 うと計算機内での処理は大幅に増大する。例えぱ、 図1(a)は東京都中野区における建物の分布を、図 1(b)は番地単位の街区の代表点の分布を、図1(c)は 丁目単位の街区の代表点の分布を表しているが、建 物は全部で 68,132 点、番地は3,421点、丁目は85点で あり、取り扱うデータが細かくなればなるほどデー 夕量が膨大になる。もし、地点デー夕(建物の代表 点)を用いた分析と集計データを用いた分析の結果 にそれほどの差異が認められなければ、処理の手間 を大幅に增大させてまで地点デー夕を用いる意義は なくなる。よって、地点データが集計データに比べ てどのような場合に有効なのかを実際に分析対象と する地域ごとに吟味する必要がある。

本論はこういった観点から、住宅地図データにお ける地点データと街区単位の集計データに招ける代 表点の分布パターン特性を調べ、さらに、この現実 の地点データと集計データを用いて利用距離に関し て検討を行い、その相違を明らかにした。また、こ れらの結夥をふまえた上で利用者が最寄りの施設を 選択することを想定したときの施設配置分析を行う 機能を付加したGISの開発を行い、これを用いて事 例分析を行うことによって地点データを利用するこ との有効性を確認した。 


\section{2. 利用者の分布}

利用者の分布状況を地点データおよび集計データ という異なる側面から捉え、分析結果に与える影響 を調べた。

地点データとは各建物内の代表点座標を点として 表現し、その点に人数が属性として付属するデータ を指す。集計データは街区やメッシュ単位に集計さ れた人ロデータで、各々の面の属性として人口が付 随するデータである。後者は、施設配置計画やエリ アマーケティング分析を定量的に扱うときには、街 区やメッシュの代表点(幾何的重心など)に人口が集 䄪されているものとして取り扱われることが多い。

地点データと集計データの代表点の分布パターン の違いを中野区について図示すると図1のようにな る。この分布バターンの特性を調べるため、ランダ ム分布からの乘離の度合を示す尺度である最近䇟測 度R（大友,1982)を求めると、図1(a)の建物分布は $\mathrm{R}=0.85$ 、図1(b)の番地単位の街区では $\mathrm{R}=1.46$ 、図 1(c)の丁目単位の街区では $\mathrm{R}=1.63$ となる。3つの図の 点の分布パターンは異なっており、図1(a)、(b)、(c) という順に集塊型から拡散型の方に変化している。 これは、本来図1(a)のように分布する利用者を図 1(b)、(c)のように集計データとして集約するに伴 い、本来持つ分布パターンが変化してしまうことを 示している。

この分布パターンの相違が利用距離の算定にどの ような影響を与えるのであろうか。

まず、利用者にとって施設選択の幅がない場合の 例として、Weber問題を例題に考察する。これは現 実には区役所の本庁のような施設を対象とした場合 にあたる。

図2は中野区内に任意の初期点を5つとり、分析の 対象として利用者分布を「図1(a)建物」と「図1(b) 番地単位の街区」とした場合について、それぞれ Weber問題を解いたものである。

すなわち、対象地域に $m$ 個の街区があり、その代 表点 $u_{1}, \ldots, u_{m}$ にそれぞれ $w_{1}, \ldots, w_{m}$ の利用者 が存在しているものとする。街区の代表点を利用者

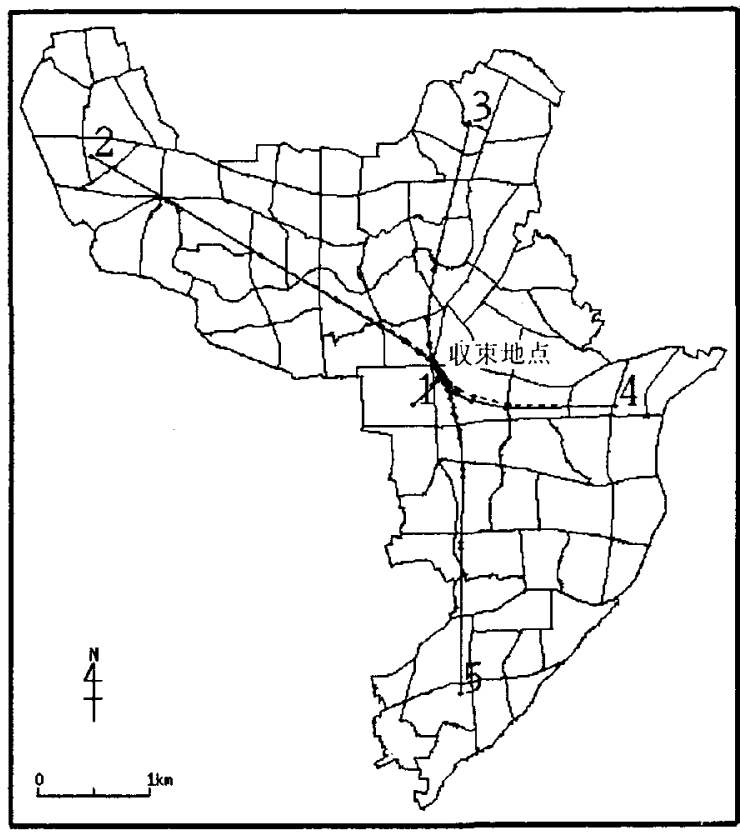

(実線:建物単位,点線:街区単位)

図 2.5つの点を初期点とした最適立地

表1 図2における収束点の座標値(注1)

\begin{tabular}{|c|c|c|}
\hline 点 & \multicolumn{2}{|c|}{ 利用者の分布 } \\
\cline { 2 - 3 } 番 & 建物単位 & 番地単位 \\
\hline 1 & $(13278.93,19166.99)$ & $(13279.47,19166.30)$ \\
2 & $(13278.82,19167.19)$ & $(13279.38,19166.49)$ \\
3 & $(13278.82,19167.19)$ & $(13279.38,19166.49)$ \\
4 & $(13278.94,19166.96)$ & $(13279.49,19166.27)$ \\
5 & $(13278.94,19166.98)$ & $(13279.49,19166.28)$ \\
\hline
\end{tabular}

分布として捉えた場合のWeber問題は、2点間の距離 をd(., .)で表すと利用者から施設までの距離の粉和 を最小化する施設の位置\$v\$を決める問題として以 下の目的関数 $f w(v)$ が与えられる。

$$
f_{w}(v)=\sum_{i=1}^{m} w_{i} d\left(u_{i}, v\right)
$$

一方，建物の代表点を利用者分布として捉えた場合 については以下のようになる。

$i$ 番目の街区には $m_{i}$ 個の建物が位置 $u_{i j}\left(j=1, \ldots, m_{i}\right)$ で与えられ、その各建物に利用者 $w_{i j}$ が存在するものとする。しかし、この各建物ご とに存在する利用者数 $w_{i j}$ は所与のデータとして与 えられていない(一般的な統計資料として入手不可 能)ので、ここでは各街区内の個々の建物に一律 
$w_{i j}=w_{i} / m_{i}$ を配分する方法をとる。各街区ごとに 各建物から施設までの距離を算出すると考えれば、 建物分布を利用者分布として捉えたWeber問題の目 的関数 $f_{B}(v)$ は以下のように記述できる。

$$
f_{B}(v)=\sum_{i=1}^{m} \frac{w_{1}}{m_{1}} \sum_{j=1}^{m_{i}} d\left(u_{i j}, v\right)
$$

この式(1)と式(2)をWeiszfeldの方法(Ostresh,1978) を用いて解き(停止条件は実際の距離で $1 \mathrm{~cm}$ とし た)、その収束の様子を示したものが図2である。い ずれも収束の際、同様な軌跡を描いてほほ同じ点に 収束し(表1)、建物分布と街区(番地単位)の代表点の 分布による差異は1mもない。

一般に集計デー夕を用いて算出した利用者から 施設までの利用距離は、真の利用距離とは異なる ことが従来より指摘されている(Hillsman andRhoda, 1978)。これは本来図3(a)のように複数の点として 分布する利用者を図3(b)のように一つの点で代表さ せてしまうことにより、各集計領域内の局所的な 人口分布パターンを無視していることによる。し かし、ここで問題としたような条件下において は、図2および表1の結果のように、街区の代表点 から施設までの距離 $d\left(u_{i}, v\right)$ と各街区内の建物から 施設までの平均距離 $1 / m_{i} \sum_{j=1}^{m_{i}} d\left(u_{i j}, v\right)$ との間には

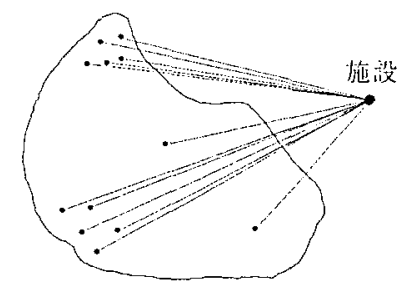

(a)地点データ

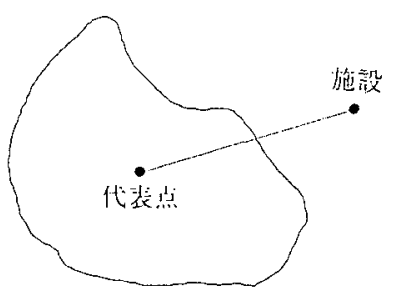

(b)集計データ
図3 任意の街区と施設の対応関係の例

表2 番地単位の街区データの性質(昭和60年)

\begin{tabular}{|c|r|r|r|}
\hline & 人口 $($ 人) & 建物 $($ 棟 $)$ & 面積 $\left(\mathrm{m}^{2}\right)$ \\
\hline 総 数 & 310,888 & 68,132 & $15,730,000$ \\
平均值 & 91 & 20 & 4,598 \\
最大值 & 1,308 & 127 & 137,441 \\
最小値 & 2 & 1 & 549 \\
標準偏差 & 84 & 14 & 4,858 \\
\hline
\end{tabular}

相違がほとんどないことがわかる。

ここでは地点データ(建物分布)と表2のような性質 を持つ集計データ(番地単位)について、Weber問題 を解いてみたが、1施設に対して利用者数が十分大 きいとして取り扱えるような場合には、局所的な人 口分布の変化は利用距離の算出に対して大きな影譬 を与えないことを意味しており、集計データ(番地 単位)を用いても満足のゆく結果が与えられること がわかる。

しかし、施設数が多くなり、1施設に対する利用 者が少なくなる場合には、このような仮定は必ずし も成立しなくなることが予想されるので、次節では この観点から調べた結果について言及する。

\section{3. 地点データと集計データの相違}

複数の施設が対象地域に分布している場合は状況が 変わり、局所的な人口分布パターンを考慮の対象に 加えなければならなくなる場合がある。

区役所等の公共サービスを提供する施設では、頻 繁に利用者が利用するサービスは本庁のみでは対処 不可能なので、出張所等を複数設置することになっ ている。小売店舗においては利用者が買い物に行く 範囲には限度があり、また複数の小壳店舗の競争が 存在し、そこには扔のずと利用圈が何らかの形で存 在する。

Huffモデル(Huff,1964)のような重力モデルにおい ては，利用圈を明確な境界線で表現しないため、前 節の結果と同様に集計データ(番地単位の街区)を利 用しても距離の算出に関してはそれほど問題ないこ とが予想される。

しかし、最奇りの施設を選択することを想定する ような場合(利用圈がVoronoi図で表現されるような 場合)、分析対象地域は複数のVoronoi領域によって 分割され、複数の利用圏に細分化される。このため 集計デー夕を用いて、分割された個々の領域内にお ける利用距離(すなわち最近隣距離)の算出や利用者 数を集計する場合、Voronoi図によって設定された 利用圈と、集計データの集計領域に幾何学的なズレ 
(図4)が生じ誤差の影響を受ける。すなわち、幾何学 的なズレが生じた面部分に存在する建物は、本来な らば最寄りと判定されるべき施設が見誤られ、その 建物が属する集計領域に与えられた代表点が最奇り とする施設に置き換わってしまっていることにな る。幾何学的にズレが生じた面部分に建物が存在し なければ問題ないが、もし多くの建物が存在すれ ば、そこから得られた結果の信憑性は低くなる。

逆に、このズレが生じた面部分に存在する建物 が、全体に占める割合が無視できる程度ならば、集 計領域を代表点で把握し、利用する方法は実用上問 題がないことになる。しかし、最寄りとする施設を 見誤られた建物は利用圈と集計領域の幾何学的なズ レと現実の局所的な建物分布パターンの重なり具合 によって変化するため、理論的に把握することは難 しい。

そこで、現実に起こっているズレの現象を確認す

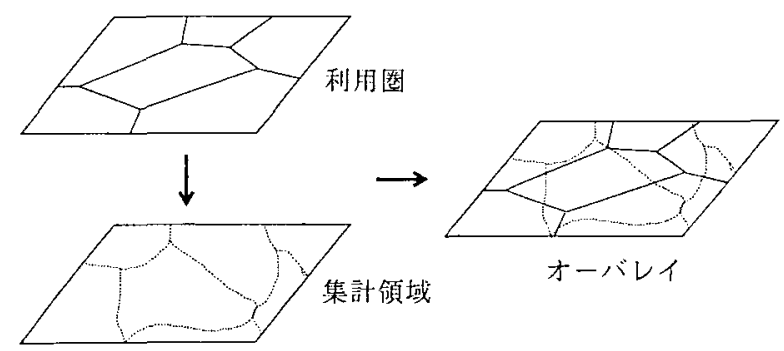

図 4. 集計領域（街区）と利用圈のズレの例

表3. 街区（番地単位）と建物の分布を用いて計測し た数值

\begin{tabular}{|c|c|c|c|c|c|c|}
\hline \multirow[b]{2}{*}{ 施設数 } & \multirow{2}{*}{$\begin{array}{r}\text { スレの面部 } \\
\text { 分の建物数 } \\
\text { (棟) }\end{array}$} & \multirow{2}{*}{$\begin{array}{c}\text { スレの面部 } \\
\text { 分の割合 } \\
(\%)\end{array}$} & \multirow{2}{*}{$\begin{array}{l}\text { 施 設 } \sigma \\
\text { 数 度 } \\
\left(\text { 棟 } / \mathrm{km}^{2}\right)\end{array}$} & \multirow{2}{*}{$\begin{array}{r}\text { 利用圈の } \\
\text { 平均面樍 } \\
\text { (ha) }\end{array}$} & \multicolumn{2}{|c|}{ 最近隣距焳 $の$ 平均值 } \\
\hline & & & & & $\begin{array}{r}\text { 建物單位 } \\
\text { (m) }\end{array}$ & $\begin{array}{r}\text { 街区単位 } \\
(\mathrm{m})\end{array}$ \\
\hline 1 & 0 & 0.00 & 0.06 & 1573.0 & 2165.3 & 2159.2 \\
\hline 2 & 336 & 0.49 & 0.13 & 786.5 & 1985.2 & 1978.4 \\
\hline 3 & 506 & 0.74 & 0.19 & 524.3 & 1738.1 & 1730.5 \\
\hline 4 & 686 & 1.01 & 0.25 & 392.3 & 1729.4 & 1722.3 \\
\hline 5 & 863 & 1.27 & 0.32 & 314.6 & 981.4 & 1002.7 \\
\hline 10 & 1535 & 2.25 & 0.64 & 157.3 & 746.5 & 772.7 \\
\hline 20 & 2234 & 3.28 & 1.27 & 78.7 & 457.2 & 461.3 \\
\hline 30 & 3096 & 4.54 & 1.91 & 52.4 & 361.6 & 368.6 \\
\hline 40 & 4233 & 6.21 & 2.54 & 39.3 & 319.0 & 323.8 \\
\hline 50 & 4615 & 6.77 & 3.18 & 31.5 & 290.8 & 296.6 \\
\hline 100 & 6907 & 10.14 & 6.36 & 15.7 & 202.5 & 206.7 \\
\hline 200 & 9833 & 14.43 & 12.71 & 7.9 & 134.7 & 139.4 \\
\hline 300 & 12027 & 17.65 & 19.07 & 5.2 & 112.8 & 115.9 \\
\hline 400 & 13308 & 19.53 & 25.43 & 3.9 & 98.6 & 101.5 \\
\hline 500 & 14662 & 21.52 & 31.79 & 3.2 & 87.5 & 90.6 \\
\hline 1000 & 19216 & 28.20 & 63.57 & 1.6 & 62.1 & 64.4 \\
\hline
\end{tabular}

るため、地点データと集計データを利用して調査し た。ある施設を中野区内に設置することを想定し、 その利用者分布として中野区に扮ける「図1(a)建 物」と「図1(b)番地単位の街区」を用い、施設の位 置は中野区内にランダムに存在するよう一様乱数に よって与えた。施設の数を1から1000まで順次増加 させた場合の利用圈(Voronoi図によって表現した)と 集計領域(番地単位)のズレの面部分に存在する建物 数と、それが中野区全体の建物数 $(68,132$ 棟 $)$ に占め る割合を調べた。

この結果は表3および図5のようになる。この結果 を見ると利用圈と集計領域(番地単位)のズレの面部 分に存在する建物数は施設の数が多くなるほど大き くなることが確認できる。このズレの面部分に存在 する建物が無視でき、集計データを用いてもよいと いえる評価基準をここで仮に全体(中野区全体の建 物総数)の $5 \%$ 以内と設定し試算を行うと以下のよう

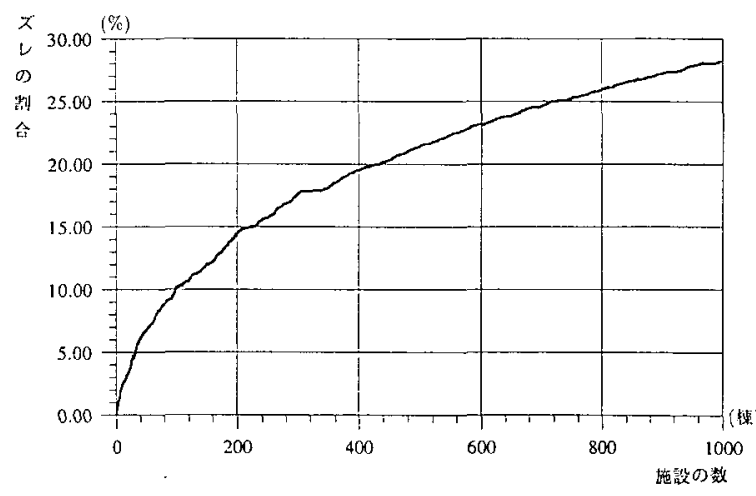

図 5. 施設の数と利用圈のズレの関係 
になる。すなわち、この仮定のもとでは施設の数が 33未满ならば集計領域を代表点で表現してもよいと いえ、施設の数がそれ以上になればスレの面部分に 存在する建物は無視できないものとなる。この施設 数33という值は、先の仮定のもとで地点データを用 いることが有効になる一つの基準値になると考えら

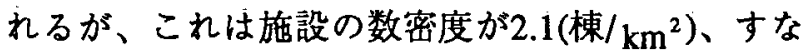
わち利用圈の平均面積が47.67(ha)のときである。こ の值を中野区の番地単位の街区の平均面積、約 0.46(ha)と照らし合わせると、一つの利用圈の面積 に対して集計領域の面の大きさは1/100程度以下で ある必要があることになる。

もちろん、この基準值は中野区において番地単位 の街区データを利用し場合に仮に設定したものであ り、分析の対象となる地域やデータが变われば変化 する性質のものである。また、表3の最近隣距離の 平均值からわかると扔りに、分析対象地域全体の平 均利用距離のみを評価項目とした分析には、集計 データ(番地単位)を用いても，利用者分布を建物ごと に捉えた場合でも、ほほ等しい䊅果が与えられる。 よって、地点データと集計データは分析の対象とな る地域や分析の目的に応じて使い分けていくことが 重要である。

\section{4. 分析のためのシステム構成}

住宅地図データを利用したGISの開発はSUN IPC 上で C言語(GNU gcc), X-WindowとX-Toolkit(Athena Widget)を用いて行った。住宅地図データは(株)ゼン リン提供のZ-mapを、データ管理は松岡(1993)によ るデータの管理体系を用いた。これに加え新たに地 点データとなる建物ファイルを作成して既存のデー タと関連付けを行った。この建物データの作成は、 住宅地図データにおける地図データから層番号32に 分類されている一般建物のみを抽出して行った。建 物ファイルは建物の位置(座標值)、人数、世帯数、 参照ファイルのアドレスから構成される。本システ ムでは、利用距離や利用者数が分析対象地域の広 さ、人口分布、施設の数とその分布バターンによっ
て変化するものであるので、分析を行うときにはこ のような観点について個々に検討できるよう地点 データと集計データのどちらも施設配置分析手段に 利用できるように設計した(図6)。分析手段として は、利用者が最寄りの施設を選択することを想定し た、特に公共施設の立地評価に有用な機能を備える ように設計し、以下のような分析を行える機能を具 備している。

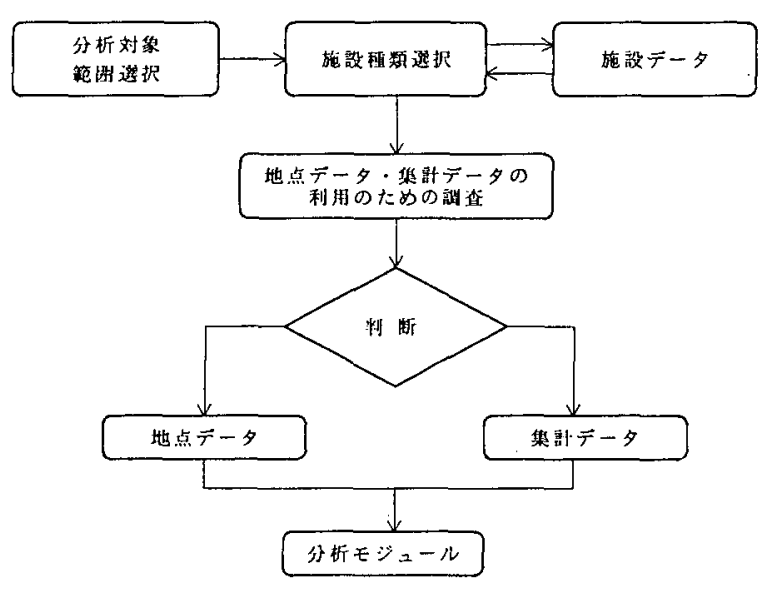

図 6. 施設配置分析の手順

1) 現状の施設配置あるいは任意の施設配置の初期点 が与えられ、それを初期配置として利用者から施設 までの総距離を最小化する施設配置を求める問題で ある minisum問題(Hansen,1987)を解くことにより最 適配置を求める。

2) 初期点として与えられた配置とその最適配置のそ れぞれの利用者から施設までの最近隣距離を算出す る。

3) 両者の距離分布とその平均利用距離、最大利用距 離を比較することにより、現状の施設配置あるいは 初期配置を評価する。

もちろん、公共施設などの施設は最適配置が求め られたとしても簡単に移設することは予算などの都 合もあってなかなかできることではない。ここでは 現状の施設配置に対する比較対象として最適配置を 導出するものであり，最適配置をそのまま現実の計 画に適用しようとするものではない。こういった施 
設配置モデルを現実に直面する計画に適用していく ためには、高度なユーザインタフェースを備えた SDSS(Spatial Decision Support System)の活用などを 考えていかなければならない(Densham and Rushton 1988, Densham and Goodchild 1989, Armstrong and Densham 1990, Willer 1990)。しかし、SDSSの研究自 体も端緒についたばかりであり、これらは今後の重 要な課題である。

\section{5. 事例分析}

構築したGISを用いた適用事例として中野区に配 置されている地域センターを取り上げる。地域セン ターは区役所の出張所、図書館等が一体化した施設 であり、中野区内に16ヶ所配置されている。各地域 センターには利用圈が設定されていないため、中野 区民であればどのセンターでも自由に利用すること ができる。図7中の黒丸(の)が現状の地域センターの 配置である。この分布パターンを見ただけでは現状 の配置が利用者にとって便利な配置なのかどうか分 からない。そこで先に述べた方法を適用し分析を 行った。

まず、現状の配置を初期点として最適配置を minisum問題の解法に基づいて求めた結果ここでは Weiszfeldの方法を用いて、停止条件を実際の距離で $1 \mathrm{~cm}$ たは探索回数の上限を70回として近似的に取 り扱った), 図7の白丸(○)のようになった。

両者の配置を距離分布で比較すると図8のように なる。最適配置の方が全体的に利用距離が短くなっ ていることがわかる。表4は距離分布の平均值、標 準偏差，最大值を示して比較したものだが、最適配 置の方が平均距離で $36.81 \mathrm{~m}$ 、最大利用距離で $300 \mathrm{~m}$ 近く短くなっていることがわかる。現状の配置には かなり改善の余地があるといえる。

これを各地域センターごとに見てみると表5の最 大利用距離揖よび平均利用距離の項目のようにな る。ほとんどの地域センターに扔いて最大利用距 離、平均利用距離ともに短くなっているが、中でも 南中野、䉆宮、上䉆宮といった地域センターでは最

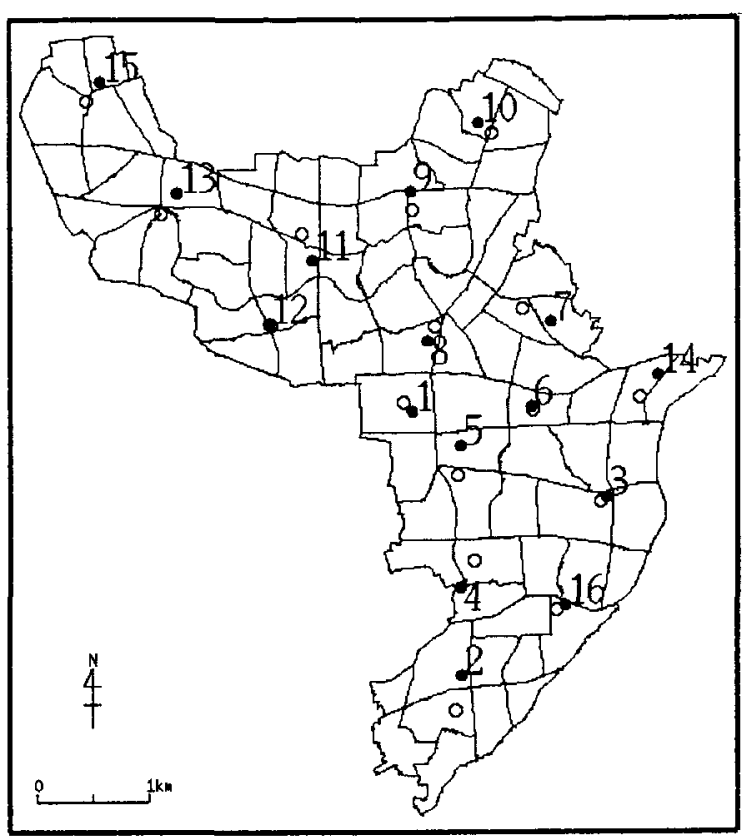

現状配置(○)と最適配置(○)

図 7. 地域センターの配置

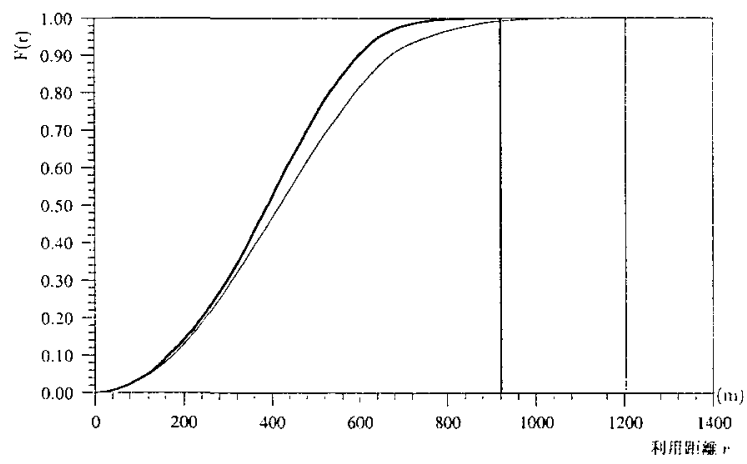

(細線:現状配置，太線:最適配置)

図 8. 距離分布

表 4. 距離分布(単位:m)

\begin{tabular}{|l|r|r|}
\hline & 現状配置 & 最適配置 \\
\hline 平均値 & 424.39 & 378.58 \\
標準偏差 & 1289.10 & 1237.73 \\
最大值 & 1203.09 & 921.56 \\
\hline
\end{tabular}

大利用距離の変化の大きさが目立つ。これらの地区 には地域センターを利用する上で不便な利用者が存 在していることがわかる。

また、利用圈内の利用者数の観点から地域セン ターの配置状況を調べると、表5の利用者数の項目 のようになった。この分析で用いたminisum問題は 利用者から施設までの総利用距離を最小化する問題 
表 5. 東京都中野区における地域センターの施設配置分析䊅果

\begin{tabular}{|c|c|c|c|c|c|c|c|c|c|c|}
\hline \multirow[b]{2}{*}{ No } & \multirow[b]{2}{*}{ センター名 } & \multicolumn{3}{|c|}{ 最大利角距䧸 $(\mathrm{m})$} & \multicolumn{3}{|c|}{ 平均利用距㒕 $(\mathrm{m})$} & \multicolumn{3}{|c|}{ 利用者数 (人) } \\
\hline & & $\begin{array}{c}\text { 現状西置 } \\
\text { (A) }\end{array}$ & $\begin{array}{c}\text { 最適配䀀 } \\
\text { (B) }\end{array}$ & $(A)-(B)$ & $\begin{array}{c}\text { 現状配置 } \\
\text { (C) }\end{array}$ & $\begin{array}{c}\text { 最薑配䈯 } \\
\text { (D) }\end{array}$ & (C) $-(\mathrm{D})$ & $\begin{array}{c}\text { 頊状配置 } \\
\text { (E) }\end{array}$ & $\begin{array}{c}\text { 最道配䀅 } \\
(\mathrm{F})\end{array}$ & $(F) /(E)$ \\
\hline 1 & 中野 & 892.89 & 860.16 & 32.73 & 446.61 & 463.93 & -17.32 & 7740 & 10091 & 1.30 \\
\hline 2 & 南中野 & 1203.09 & 921.56 & 281.53 & 499.57 & 420.41 & 79.16 & 27358 & 24761 & 0.91 \\
\hline 3 & 東部 & 791.98 & 735.46 & 56.51 & 414.06 & 400.93 & 13.13 & 22118 & 20948 & 0.93 \\
\hline 4 & 鍋横 & 788.71 & 808.66 & -19.95 & 424.25 & 367.09 & 57.14 & 19451 & 20417 & 1.05 \\
\hline 5 & 挑園 & 786.45 & 692.32 & 94.13 & 410.25 & 342.36 & 67.89 & 16493 & 16044 & 0.97 \\
\hline 6 & 昭和 & 690.80 & 675.68 & 15.12 & 349.58 & 347.25 & 2.33 & 15438 & 16296 & 1.06 \\
\hline 7 & 上高田 & 918.24 & 793.94 & 124.30 & 403.04 & 358.74 & $44.30^{\prime}$ & 15175 & 17438 & 1.15 \\
\hline 8 & 新井 & 795.35 & 766.53 & 28.82 & 390.68 & 354.06 & 36.62 & 18913 & 15993 & 0.85 \\
\hline 9 & 沼袋 & 861.89 & 745.62 & 116.27 & 415.89 & 383.40 & 32.49 & 20794 & 20010 & 0.96 \\
\hline 10 & 江古田 & 903.01 & 781.88 & 121.13 & 391.70 & 371.92 & 19.78 & 14652 & 15173 & 1.04 \\
\hline 11 & 野方 & 947.35 & 845.98 & 101.37 & 449.67 & 418.84 & 30.83 & 22216 & 21729 & 0.98 \\
\hline 12 & 大和 & 879.62 & 769.22 & 110.40 & 403.07 & 388.02 & 15.05 & 20674 & 20693 & 1.00 \\
\hline 13 & 第宮 & 1039.96 & 865.68 & 174.28 & 521.21 & 460.91 & 60.30 & 21813 & 19845 & 0.91 \\
\hline 14 & 東中野 & 624.06 & 546.12 & 77.94 & 343.91 & 294.96 & 48.95 & 5743 & 8685 & 1.51 \\
\hline 15 & 上蕗宮 & 1001.41 & 853.71 & 147.70 & 461.07 & 422.51 & 38.56 & 13376 & 14062 & 1.05 \\
\hline 16 & 弥生 & 758.26 & 727.38 & 30.88 & 366.55 & 362.80 & 3.75 & 21643 & 21412 & 0.99 \\
\hline \multirow{2}{*}{\multicolumn{2}{|c|}{ 平㨁 }} & - & - & - & 399.61 & 362.80 & 36.81 & 177248 & 17724.8 & 1.00 \\
\hline & & - & - & - & - & - & - & 56079 & 4344.9 & $=$ \\
\hline
\end{tabular}

であり、施設が抱える利用者数を均等化する問題で はないが、ここでは最適配置の方が各地域センター 間の利用者数の散らばりが小さくなることが標準偏 差よりわかる。この原因は現状の配置において南台 など地域センターが設置されていない地区や弥生町 のように2つ設置されている地区があることなどに よってアンバランスが生じているためと考えられ る。

\section{6. おわりに}

本論では施設配置分析やエリアマーケティング分 析において必ず直面する利用者デー夕の取り扱い方 を利用距離に関して検討した。中野区を対象とした 結果では、施設に対して利用者が十分に多ければ集 計データ(番地単位)を用いてもかなりの精度がある ことが確認できた。しかし、利用者が最寄りの施設 を選択することを想定した分析においては、施設の 数が多くなると集計データの集計領域と利用圏との ズレの面部分に存在する建物数が大きくなり、集計 データでは対応できていないことが明らかとなっ た。この場合は利用者分布を建物ごとに捉える地点 データを活用することが有用となる。

もちろん、この地点データと集計デー夕の使い分 けは、分析の対象となる地域およびその広さ、人口 分布，施設の数掞よびその分布パターンによって変 化するものであるから、分析を行うときにはこのよ
うな観点について対象とする地域ごとに検討を加え る必要があり、これを容易に実現するための機能を 付加したGISの構筑を合わせて行った。2節、3節の 結果はこのシステムからのアウトプットをまとめた ものであり、このような機能はGISの重要な機能の 一つとして認識する必要がある。

今後の課題としては、集計領域と利用圈のズレの面 部分に存在する建物の空間分布に関する理論化を進 めるとともに、多くの地域を対象とした実証的な事 例をふんで一般的に捉えていく必要がある。また、 本論ではこのズレの問題を平面上で取り扱ったが、 道路ネットワーク上でも調べる必要がある。

(補注)

1) 座標はZ-mapにおける地図座標を変換したもの。 単位は $10 \mathrm{~cm}$ である。

\section{参考文献}

大澤義明, 腰塚武志(1983) 距離分布による施設配置 の分析, 旧本都市計画学会学術研究論文集」,

18, 25-30.

大友 篤(1982)「地域分析入門」, 東洋経済新報社. 鶴谷建之, 笠原裕, 宮下敏昭(1985) 地域分析のため

の地理情報のオーバレイ手法, 「電子情報通信

学会論文誌 , J68-D, 183-192.

松岡公二(1993) 電子住宅地図を利用したGISのデー 
夕管理方法の検討, [GIS一理論と応用」, 1, 67-

80.

Armstrong, M.P., Densham, P.J.,(1990) Database

Organization Strategies for Spatial Decision

Support Systems, International Journal of

Geographical Information Systems, 4, 3-20.

Densham, P.J., Rushton, G.,(1988) Decision Support

Systems for Locational Planning, in Behavioural

Modelling in Geography and Planning, eds.

R.Golledge and H.Timmermans, 56-90, London:

Croom-Helm.

Densham,P.J., Goodchild, M.F.,(1989) Spatial Decision

Support Systems:Research Agenda, Proceedings

GIS/LIS'89 ACSM, 707-716.

Hansen, P.,(1987) Facility Location Analysis, in

Systems of Cities and Facility Location, eds.

P.Hansen et al., 1-70, Chur.: Harwood Academic

Publishers.

Hillsman, E.L., Rhoda, R.,(1978) Errors in Measuring

Distances from Populations to Service Centers,

Annals of Regional Science, 12, 74-88.

Huff, D. L.,(1964) Defining and Estimating a Trading Area, Journal of Marketing, 28, 34-38.

Ostresh, L. M. Jr.,(1978) On the Convergence of a Class of Iterative Methods for Solving the Weber Location Problem, Operations Research, 26, 597 609.

Willer, D.J.,(1990) A Spatial Decision Support System for Bank Location: A Case Study, National Center for Geographic Information and Analysis,

Technical Report 90-9. 